\title{
Deepwater Spawning of Fall Chinook Salmon (Oncorhynchus tshawtscha) Near Ives and Pierce Island of the Columbia River
}

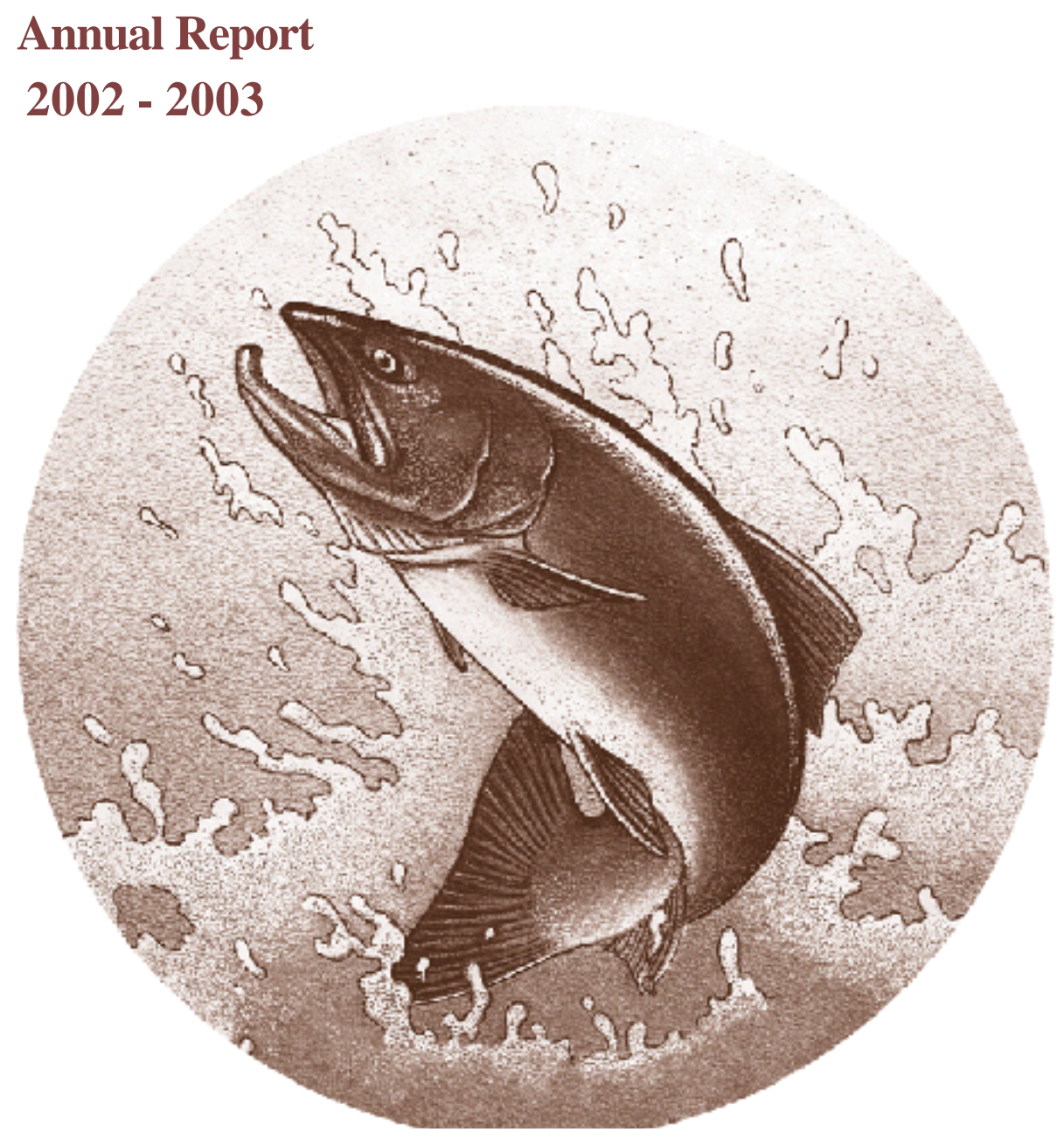

DOE/BP-00000652-13

September 2003 
This Document should be cited as follows:

Mueller, Robert, "Deepwater Spawning of Fall Chinook Salmon (Oncorhynchus

tshawtscha) Near Ives and Pierce Island of the Columbia River", Project No. 1999-00301,

29 electronic pages, (BPA Report DOE/BP-00000652-13)

\author{
Bonneville Power Administration \\ P.O. Box 3621 \\ Portland, Oregon 97208
}

This report was funded by the Bonneville Power Administration (BPA), U.S. Department of Energy, as part of BPA's program to protect, mitigate, and enhance fish and wildlife affected by the development and operation of hydroelectric facilities on the Columbia River and its tributaries. The views in this report are the author's and do not necessarily represent the views of BPA. 


\title{
Deepwater Spawning of Fall Chinook Salmon (Oncorhynchus tshawytscha) near Ives and Pierce Island of the Columbia River, 2002
}

\author{
Robert P. Mueller \\ Pacific Northwest National Laboratory ${ }^{1}$ \\ Richland, Washington 99352
}

September 2003

Submitted to Bonneville Power Administration

Portland, Oregon

\footnotetext{
${ }^{1}$ Pacific Northwest National Laboratory is operated for the U.S. Department of Energy by the Battelle Memorial Institute under contract DE-AC06-76RLO 1830.
} 


\section{Summary}

Pacific Northwest National Laboratory conducted video-based boat surveys to identify fall chinook salmon (Oncorhynchus tshawytscha) spawning areas located in deep water (>1 m) downstream of Bonneville Dam in the fall of 2002. This report documents the number and extent of chinook salmon spawning near Ives and Pierce Islands of the Columbia River, and is the fourth in a series of reports prepared since 1999. The main objective of this study was to find deepwater spawning locations of fall chinook salmon in the main Columbia River channel, collect additional data on physical habitat parameters at spawning sites, and provide estimates of adult spawners in the surveyed area. The secondary objective was to document the occurrence of any chum salmon (O. keta) redds located in the deeper sections near below Hamilton Creek.

There was a significant increase in the number of fall chinook salmon redds found in the locations surveyed during the 2002 surveys when compared to previous surveys by Pacific Northwest National Laboratory. A total of 192 redds were found in two general locations adjacent to Pierce Island (river km 228.5) encompassing an area of approximately 9.31 ha. Peak spawning activity, based on redd counts and live fish seen near redds, was on or near November 15, 2002. An estimated 1,768 fall chinook salmon redds at water depths exceeding $\sim 1 . \mathrm{m}(\sim 125 \mathrm{kcfs})$ were documented in 2002. This estimate is the expanded number based on the number of redds found within the predefined survey area. Fall chinook salmon redds were found at water depths from 0.9 to $8.5 \mathrm{~m}$ and were constructed in gravel to large cobble ranging in size from 4.83 to $13.4 \mathrm{~cm}$ in diameter. No chum salmon redds were found in areas surveyed during 2002, although several carcasses were found at the mouth of Woodward Creek and in the deeper sections below Hamilton Creek. 


\section{Acknowledgements}

The author thanks Scott Titzler, Corey Duberstein, and Nate Phillips for their assistance in conducting the surveys and in analysis of the videotapes. David Geist reviewed earlier drafts of this report. 


\section{Contents}

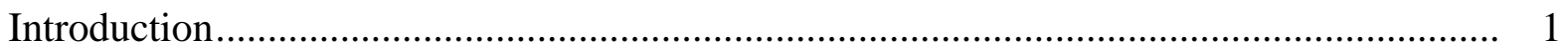

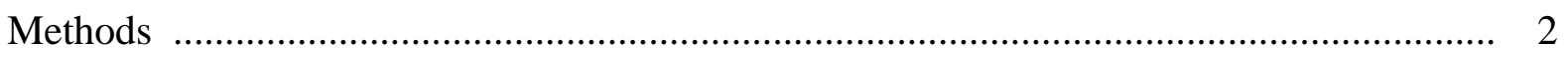

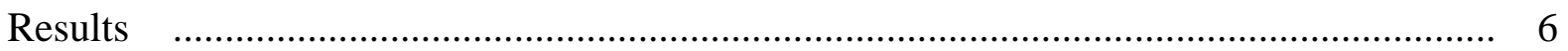

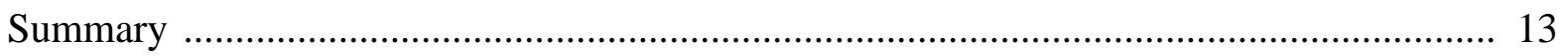

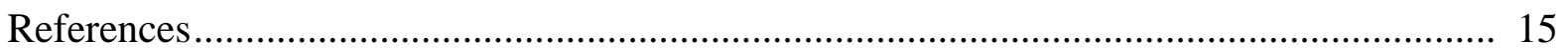

Appendix A - PNNL Redd Coordinates ……................................................................... A.1

\section{Figures}

1 Location of search zones in relation to Ives and Pierce Islands .............................. 3

2 Location of fall chinook salmon redds in the mainstem of the Columbia River below Bonneville Dam 2002 ................................................................................... 7

3 Distribution of fall chinook salmon redds $(n=192)$ relative to water depth found during the November and December 2002 surveys ................................................ 9

4 Dominant substrate classification of fall chinook salmon redds .............................. 9

5 Salmon carcasses found near the mouth of Woodward Creek on November 20, 2002.10

$6 \quad$ Fall chinook salmon spawning area for redds found during 2002 ......................... 11

7 Location of fall chinook salmon redds in the mainstem of the Columbia River below

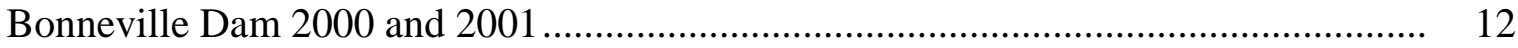

$8 \quad$ River flow at Bonneville Dam near Pierce Island for 2000 and 2001 ...................... 13 


\section{Tables}

1 Substrate categories used for spawning habitat classification .............................. 5

2 River Flow and elevation conditions during the underwater video survey periods. ..... 6

3 Estimated number of fall chinook salmon redds occurring in the primary search

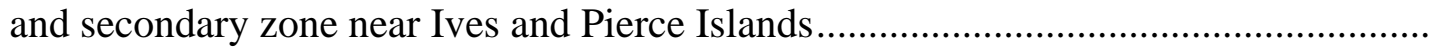

4 Peak fall chinook redd numbers and approximate spawning areas from 1999-2002 near Ives and Pierce Islands 


\section{Introduction}

Pacific Northwest National Laboratory (PNNL) conducted this study to identify fall chinook salmon (Oncorhynchus tshawytscha) spawning locations and assess habitat variables downstream of Bonneville Dam in 2002, the fourth year of such study. Fall chinook salmon have been documented using Ives and Pierce Islands, located downstream of Bonneville Dam, for spawning since 1993 (Hymer 1997). The size of this population was estimated at 1,800 to 5,200 fish from 1994 to 1996 (Hymer 1997). In more recent years, an adult population of 704 adult fish was estimated in 2000 (Van der Naald et al. 2000-2001) and 721 adult fish in 2001 (Van der Naald et al. 2001-2002). These estimates are based on carcass tagging and recoveries near shallow water and do not take into account fish that spawn nearer the main river channel. PNNL conducted underwater video surveys from 1999 through 2002 to estimate the number of fall chinook salmon redds occurring in deeper water $(>1 \mathrm{~m})$. Extrapolated estimates of fall chinook salmon redds were 754 in 1999 (at $143 \mathrm{kcfs}$ ), 787 redds (at $127 \mathrm{kcfs}$ ) in 2000 (Mueller 2001) and 717 (at $85 \mathrm{kcfs}$ ) in 2001 (Mueller 2002). All of the fall chinook salmon redds were found adjacent to Pierce Island.

The main objective of this study was to locate and map deepwater spawning areas of fall chinook salmon near the main Columbia River channel and to collect additional data on the physical habitat at spawning sites. The secondary objective was to map any chum salmon $(O$. keta) redds located in deeper sections in and around Ives and Pierce Islands. 


\section{Methods}

The survey area for this study consisted of three different search zones located

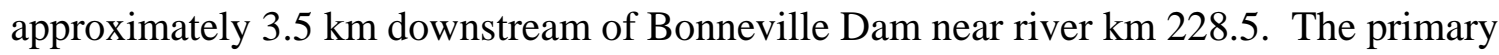
zone $\left(125,000 \mathrm{~m}^{2}\right)$ located along the main channel side of Pierce Island was segmented into regularly spaced transects, $20 \mathrm{~m}$ apart and $160 \mathrm{~m}$ in length (37 total), running perpendicular to the shoreline. The secondary zone $\left(60,350 \mathrm{~m}^{2}\right)$ was located at the lower end of Pierce Island and consisted of 18 additional transects, $25 \mathrm{~m}$ apart and $120 \mathrm{~m}$ in length. The third search zone (slough area) consisted of two separate areas with the first occurring at the lower end of Pierce Island and the second within Hamilton Slough between Ives and Pierce Islands (Figure 1). These areas were established based on pervious surveys which documented redd occurrences (Mueller and Dauble 2000; Mueller 2001, 2002).

Two separate underwater video boat surveys were conducted in late November and early December 2002. The peak spawning date for fall chinook salmon was determined to be November 15 based on visual observations of adult fish by the Oregon Department of Fish and Wildlife (ODFW). Due to low water elevation, only a limited area was searched within the Hamilton Slough. 


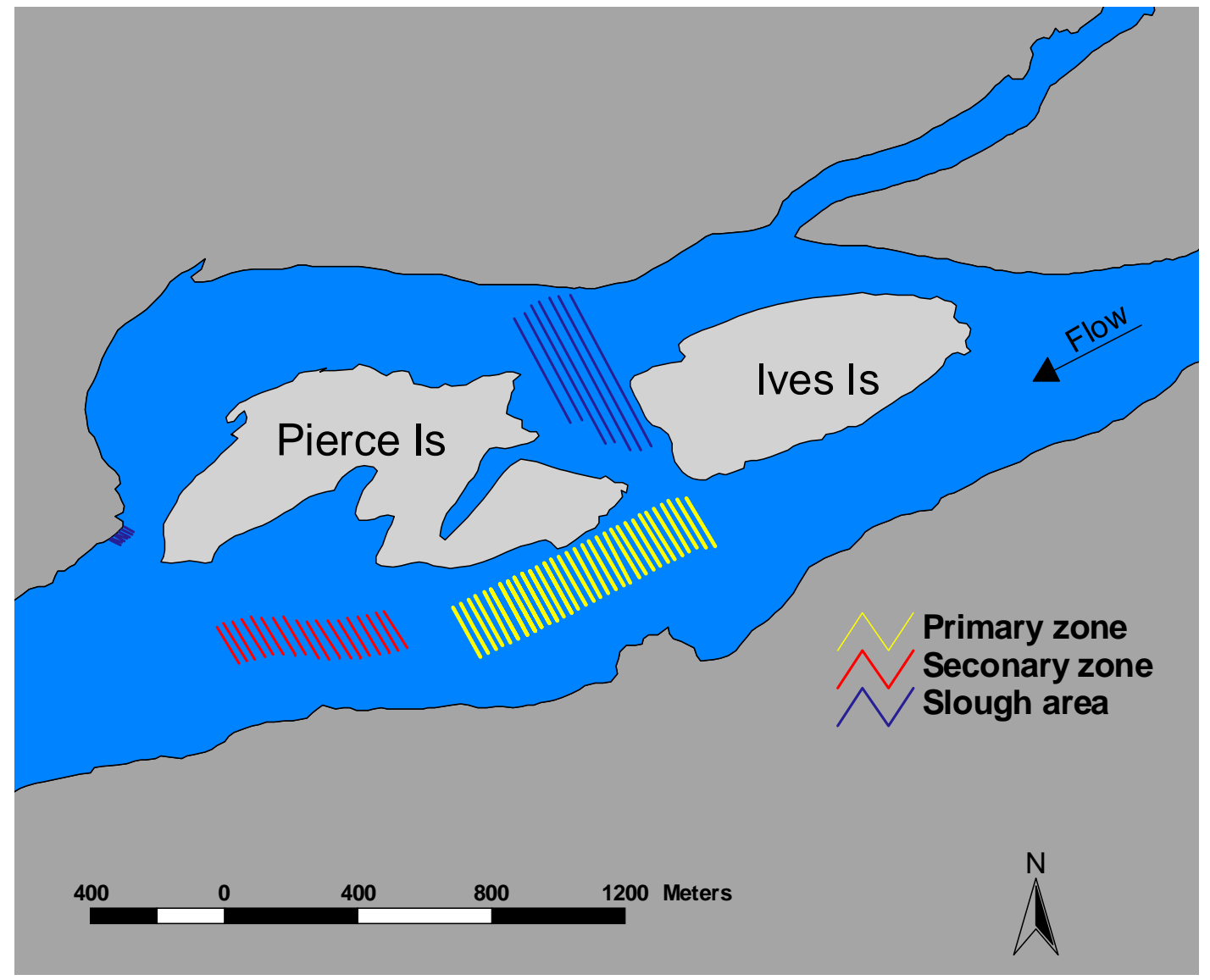

Figure 1. Location of search zones in relation to Ives and Pierce Islands.

The boat-deployed video system consisted of a high-sensitivity remote camera (Deep Sea Model 1050) attached to a weighted platform. Recordings were made using a Sony (model GVD 7000) digital 8-mm recorder located on the survey vessel. Two highresolution monitors were used during the surveys for better viewing of the video obtained by the remote camera. An integrated video/tow cable attached to a manual winch with slip ring mechanisms was used to raise and lower the sled to the desired depth. Visual images of redds and bottom substrate were recorded using an underwater video system according to procedures described in Dauble et al. (1999). Redds were easily distinguished from the surrounding substrate as areas of clean substrate, with a typical redd pit and tail spill shape, in contrast to areas of dark-colored (periphyton-covered) substrate. Live fish were often observed on the video screen when redds were found. 
The maximum depth where adequate visual image could be obtained depended on water turbidity and ambient light levels. An on-board, real-time Differential Global Positioning System (DGPS) (Trimble Pathfinder ${ }^{\mathrm{TM}}$ Pro XR) was used to collect positional data and to navigate on pre-set transect grids during the surveys. The integrated DGPS beacon receiver and antenna provided DGPS corrections to calculate sub-meter accuracy $(\sim 0.5$ m). The system's software (ASPEN) displayed a background map of the study site on a personal computer so that researchers could navigate to site locations on a pre-determined transect line and visually verify data accuracy in the field. Both the GPS and video system were synchronized via a time stamp. When a redd was encountered, the time was noted in the logbook as well as a point position with the GPS. Further analysis and verification of redds was performed in the lab. The location of any new redds was also mapped to Arc/View ${ }^{\circledR}$ graphic information system (GIS).

Determination of the type and size of the substratum was achieved by using underwater red lasers C-map systems (model HL6312G). The lasers were mounted in parallel on the weighted platform at either side of the camera $18.4 \mathrm{~cm}$ apart. The lasers provided a reference scale within the camera image. The distance from the camera lens to the substratum ranged from 0.9 to $1.4 \mathrm{~m}$, providing an effective view path of $\sim 2.7 \mathrm{~m}^{2}$ along each transect ( $1.5 \mathrm{~m}$ vertical). Grain size was determined by digitizing the image when the camera was positioned near the center portion of the redd and processing the image using an imaging software program $\left(\right.$ Optimas $\left.^{\circledR}\right)$. To remove bias in obtaining measurements, a single rock which was contacted by the right laser beam was measured (long axis diameter). The substrate size for each redd was classified according to five general size categories (Table 1). 
Table 1. Substrate categories used for spawning habitat classification (modified from Platts et al. 1983).

\begin{tabular}{||c|l|c||}
\hline Category & Sediment Classification & $\begin{array}{c}\text { Long Axis Diameter of } \\
\text { Individual Substrate }(\mathrm{cm})\end{array}$ \\
\hline \hline 1 & Fines, silt & $<0.61$ \\
\hline 2 & Gravel & $0.6-7.6$ \\
\hline 3 & Medium cobble & $7.6-15.2$ \\
\hline 4 & Large cobble & $15.2-30.5$ \\
\hline 5 & Boulder & $>30.5$ \\
\hline
\end{tabular}

To eliminate the possibility of counting a redd more than once during the two survey periods, we omitted any redds that fell within a $\sim 1.8$-m radius of a nearby redd. This distance was based on an overall redd size of $10 \mathrm{~m}^{2}$, which is indicative of fall chinook salmon redds within the Columbia River (Burner 1951; Chapman et al. 1983; Visser 2000). In addition, the cumulative number of redds found during both survey periods was extrapolated to estimate the total number of redds constructed within the primary search zone. These estimates were calculated by taking the total number of redds found during each of the surveys and expanding this number based on the percent coverage (assuming normal distribution) within the total search zone. The total fall chinook salmon redd estimates do not include redds found by other researchers conducting visual redd observations by boat.

Turbidity was recorded using a LaMotte (model 2008) turbidimeter. Recorded tapes were reviewed in detail at the PNNL computer lab using a high-resolution monitor. Bathymetric data was obtained using a one-dimensional, unsteady river flow and water quality computer model MASS1 (Modular Aquatic Simulation System 1D), developed at PNNL. 


\section{Results}

Initial deepwater redd surveys of the main channel near Ives and Pierce Islands were completed on November 19 to 21, 2002, after the peak spawning date of November 15 for fall salmon (FPC 2003). Water turbidity averaged 1.8 nephelometric turbidity units (NTU), and river flows recorded at Bonneville Dam ranged from 126 to $193 \mathrm{kcfs}$ (Table 2). A total of 93 fall chinook salmon redds were located and mapped within the primary search zone and 31 in the secondary zone. One redd was found near the mouth of McCord Creek near the Oregon shoreline. No chum redds were found during the surveys within Hamilton Slough and near the mouth of Woodward Creek, although many carcasses were found at both locations.

The second deepwater fall chinook salmon redd survey was completed on December 10 to 11, 2002. Average river flows at Bonneville Dam during the survey period were $124 \mathrm{kcfs}$ and water turbidity averaged 1.85 NTU's. A total of 52 new fall chinook salmon redds were found in the primary search zone and 16 in the secondary zone. A number of fall chinook carcasses were also found in the deeper sections of the secondary zone. These were found at the lower transects (10 to 18) nearest Pierce Island. Low water elevation precluded the surveying of the channel between Ives and Pierce Islands; a river flow exceeding $135 \mathrm{kcfs}$ is required to effectively survey this area. The maximum depth where redds could be detected was $8.5 \mathrm{~m}$ during both surveys.

Table 2. Average river flow and elevation conditions recorded during the underwater video survey period.

\begin{tabular}{|l|c|c||}
\hline Date & $\begin{array}{c}\text { Discharge at Bonneville } \\
\text { Dam (kcfs) }\end{array}$ & $\begin{array}{c}\text { Ives Island Staff } \\
\text { Gage 1 (ft) }\end{array}$ \\
\hline Nov. 19 & 193 & 0.94 \\
\hline Nov. 20 & 126 & 0.97 \\
\hline Nov 21 & 127 & 1.02 \\
\hline Dec 10 & 122 & 1.13 \\
\hline Dec. 11 & 126 & 0.71 \\
\hline
\end{tabular}


The location of all redds $(\mathrm{n}=193)$ found during surveys conducted in 2002 is shown in Figure 2. The MASS1 model was superimposed on the river layer to illustrate the redds in relation to water depth at a river flow of $125 \mathrm{kcfs}$ at Bonneville Dam. A listing of all fall chinook salmon redd coordinates found near the main river channel, water depth, and dominant substrate size is listed in Appendix A.

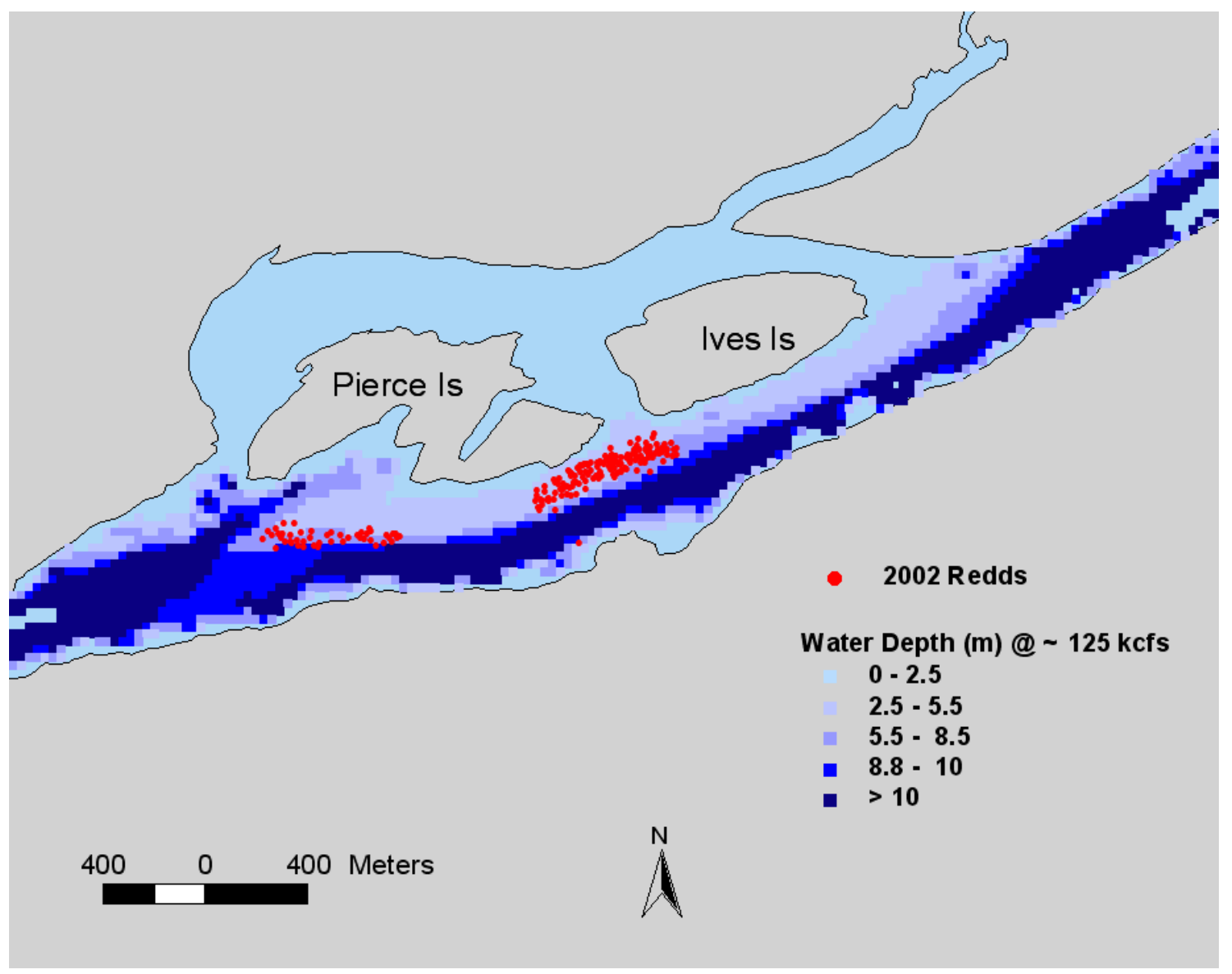

Figure 2. Location of fall chinook salmon redds $(n=193)$ in the mainstem of the Columbia River below Bonneville Dam in 2002. 
Water depths at redd locations ranged from 0.91 to $8.53 \mathrm{~m}$ at a river flow of $\sim 125$ kcfs (Figure 3). The majority of the redds were found in water depths of 1 to $5 \mathrm{~m}$. Substrate measurements were obtained from each redd found by using the lasers for scaling. The long axis diameter for redds measured $(n=185)$ ranged from 4.83 to 19.3 $\mathrm{cm}$. The vast majority (85\%) fell into the medium cobble classification (Figure 4). The substrate size tended to increase towards the main river channel and decrease nearer the Pierce Island shoreline.

The surveys conducted within the Hamilton Slough occurred along the northern shoreline between the islands downstream from the majority of chum salmon spawning area. A number of carcasses were found in this area that were identified as chum carcasses based on size and coloration. A total of 11 carcasses were found during the search. We did not observe any definitive salmon redds during the limited survey conducted at the mouth of Woodward Creek and along the shoreline downstream of the creek. We did observe many carcasses $(>15)$ grouped together in a relatively small area in deeper water at the mouth of Woodward Creek (Figure 5). A total of 11 carcasses were found during downstream of Hamilton Creek. 


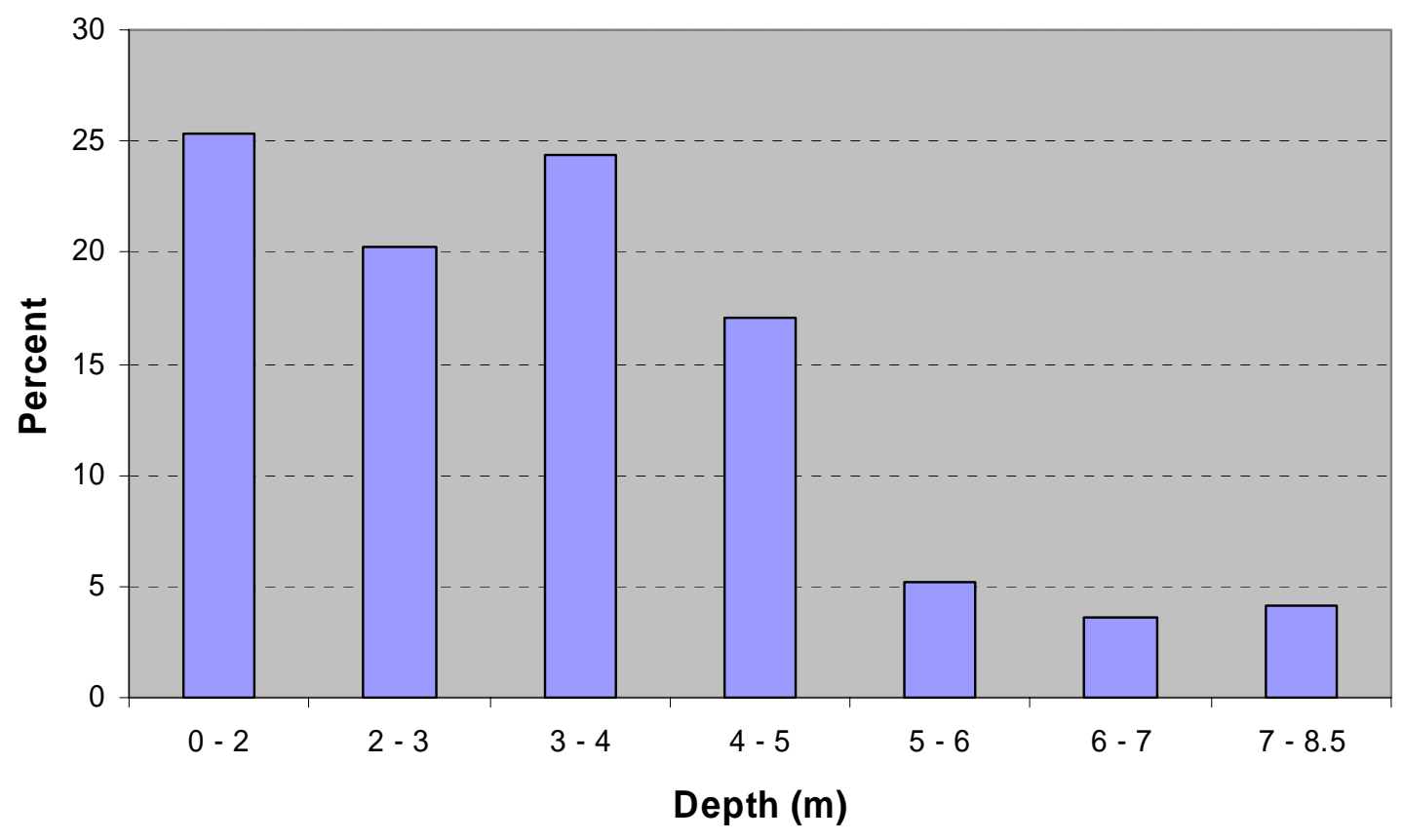

Figure 3. Distribution of fall chinook salmon redds $(n=193)$ relative to water depth during the November and December 2002 surveys (flow $125 \mathrm{kcfs}$ ).

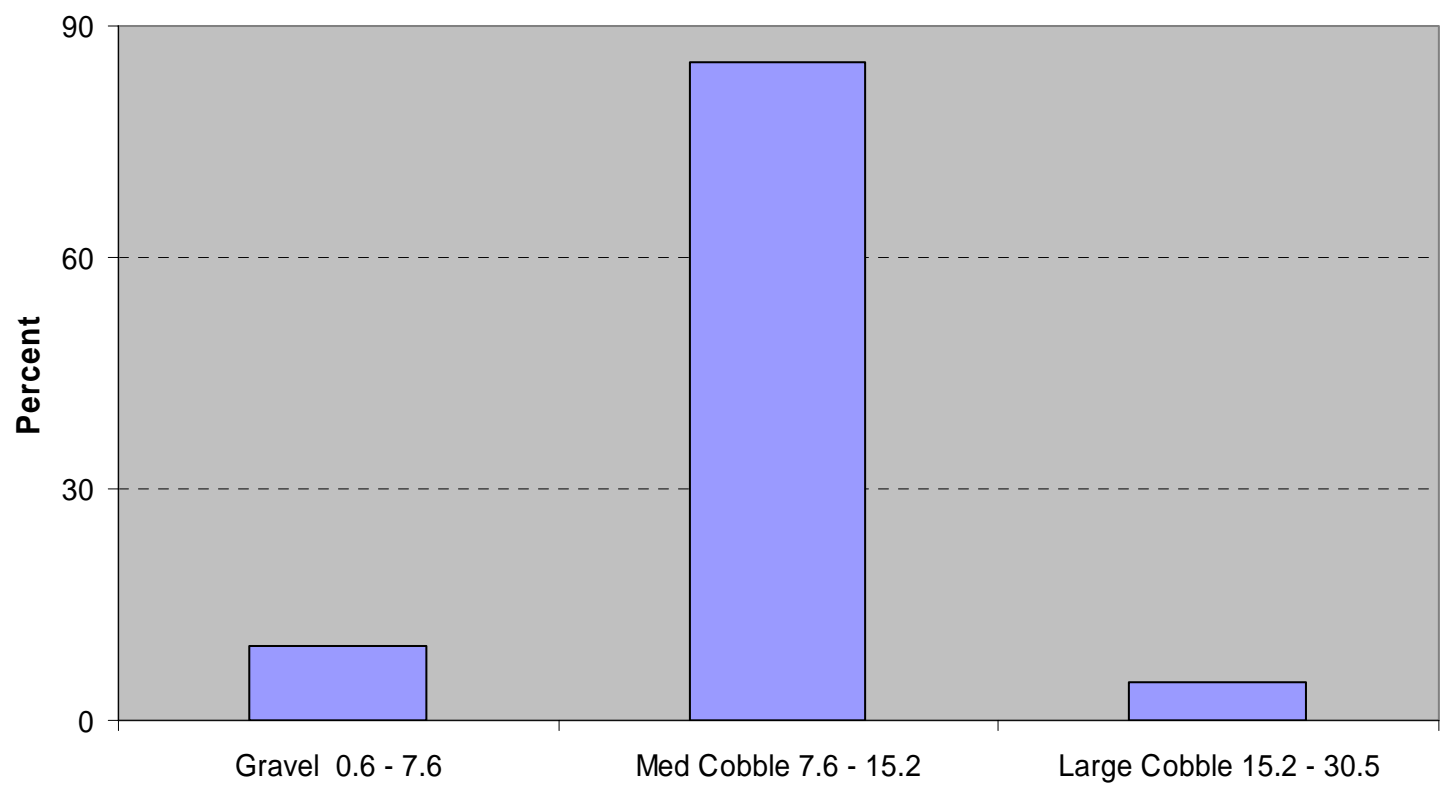

Figure 4. Dominant substrate classification of fall chinook salmon redds $(\mathrm{n}=185)$ 

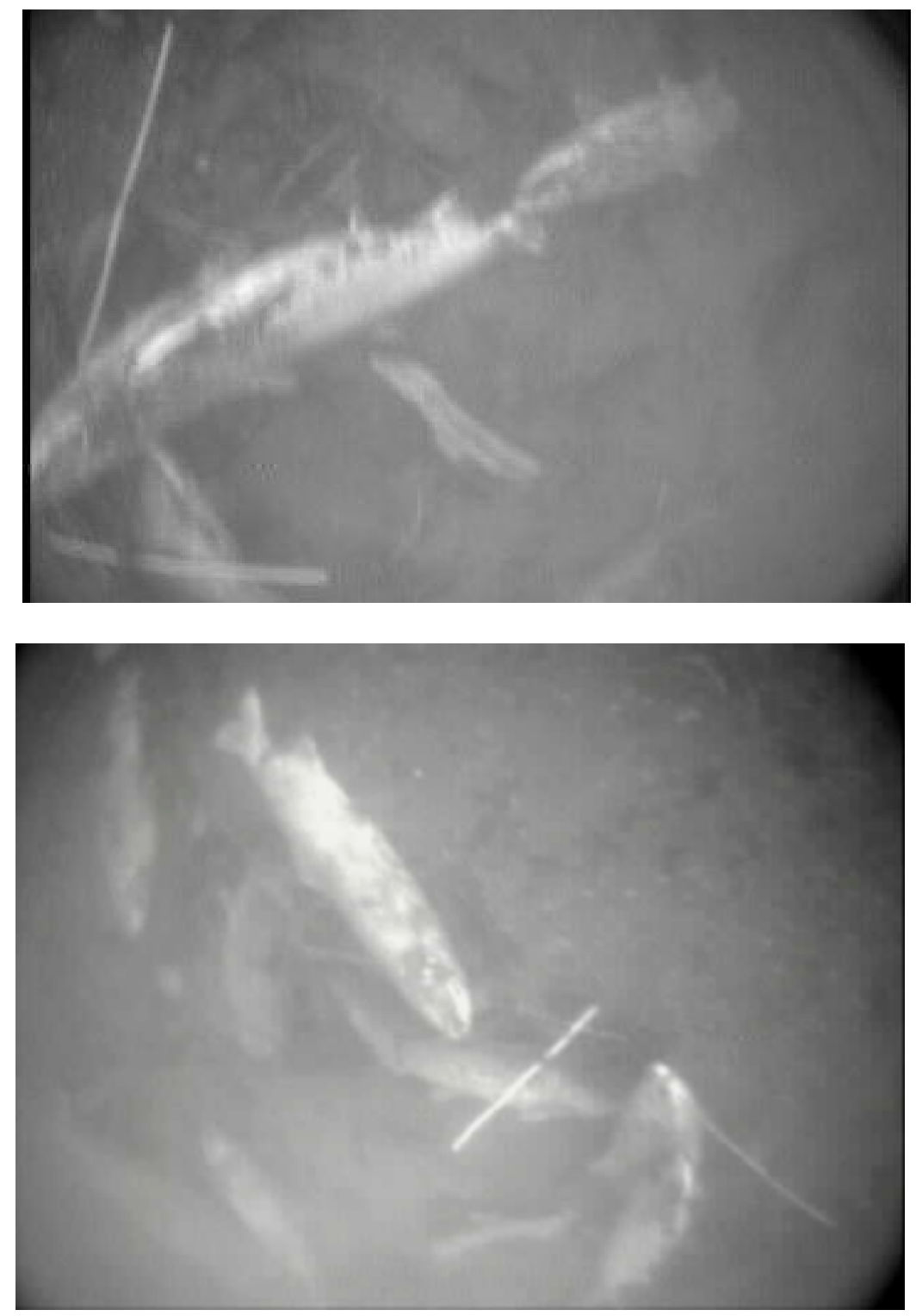

Figure 5. Salmon carcasses found near the mouth of Woodward Creek on November 20, 2002. 
The total area fall chinook salmon used for spawning was calculated by drawing a boundary line around the redd locations within the primary and secondary zones. The area where redds were found encompassed 6.4 ha in the primary and 2.9 ha in the secondary zone (Figure 6).

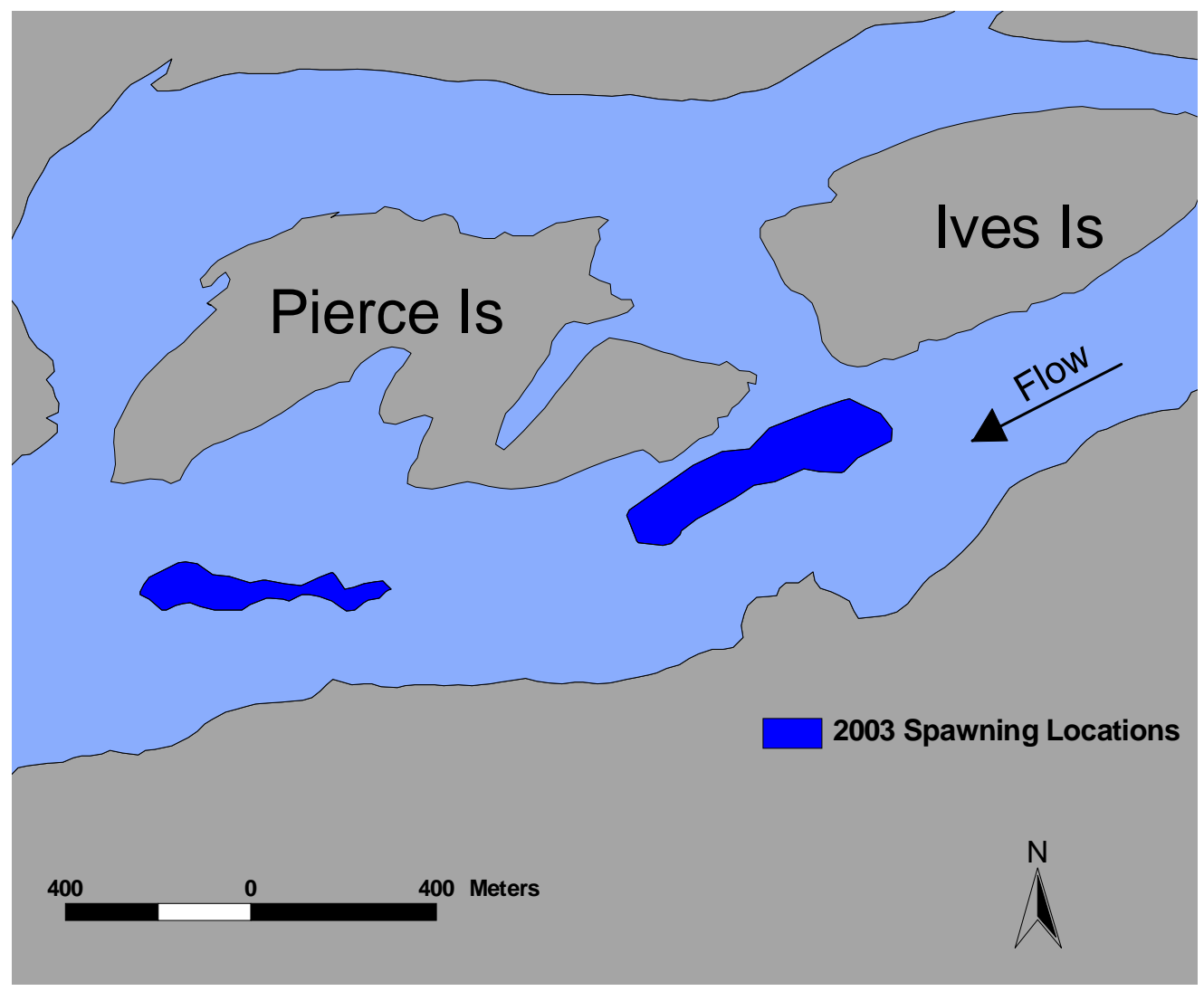

Figure 6. Fall chinook salmon spawning area for redds found during 2002.

During the past 3 years of deepwater redd surveys by PNNL, a total population of spawning fish was estimated by extrapolating the redd count based on the portion of the area surveyed by video camera. The counts were expanded assuming equal distribution throughout the zone where redds were found. For the 2002 surveys, the vertical coverage along each transect line was estimated to be approximately $1.5 \mathrm{~m}$. Because the boat route 
varied somewhat along each transects line, an average distance traveled was estimated using the actual boat track. The actual redd count was used to estimate the total number of redds which may be present in the overall survey zone assuming equal distribution of redds that could occur in this zone. This redd estimate was then used to estimate the total spawning population within the spawning areas (Figure 6) by multiplying each redd by a (redd to adult ratio) of 3.4 (Visser 2000).

Spawning populations of fall chinook salmon have remained relatively constant from 1999 to 2001 with an average of 2,556 adult fish using the deepwater sections $(>1.5$ m) adjacent to Pierce Island (Mueller 2002). During 2002, personnel from ODFW counted a total of 214 fall chinook salmon redds at the estimated peak spawning date of November 15, 2002, within the Ives and Pierce Islands area by wading or observation by boat (FPC 2003). PNNL estimated that an adult spawning population of 6,011 fall chinook salmon used the near-shore and deeper water area adjacent to Pierce Island during 2002 (Table 3). This estimate was based on the November survey when the maximum number of redds were found corresponding to the peak of the spawning period.

Table 3. Estimated number of fall chinook salmon redds occurring in the primary search and secondary zone near Ives and Pierce Islands during the peak spawning period, November 20-21, 2002.

\begin{tabular}{|l|c|c|c|c|c||}
\hline Location & $\begin{array}{c}\text { Total } \\
\text { Area } \\
\text { Surveyed } \\
\left.\mathbf{( m}^{\mathbf{2}}\right)^{*}\end{array}$ & $\begin{array}{c}\text { Percent Video } \\
\text { Coverage }\end{array}$ & $\begin{array}{c}\text { Number of } \\
\text { Redds Found }\end{array}$ & $\begin{array}{c}\text { Adult } \\
\text { Extrapolated } \\
\text { Redd Estimate }\end{array}$ & $\begin{array}{c}\text { Population } \\
\text { Estimate }\end{array}$ \\
\hline \hline Primary & 4,500 & 6.81 & 93 & 1,366 & 4,644 \\
\hline Secondary & 2,320 & 7.71 & 31 & 402 & 1,367 \\
\hline Total & 6,820 & & 124 & 1,768 & 6,011 \\
\hline
\end{tabular}

* Area encompassed the survey boat track and average transect length in each survey zone based on a 1.5-m video field view along each transect. 


\section{Discussion}

The 192 fall chinook salmon redds found to occur near the vicinity of Ives and Pierce Islands downstream of Bonneville Dam in 2002 was the highest number observed during the last 4 years of similar surveys by PNNL. The majority of the redds for all years were found adjacent to Pierce Island. A larger than expected number (47) were found within the secondary search zone from both surveys during 2002. Only a handful of redds were found there during the 2000 survey and none were found in 1999 and 2001. The increase in the number of redds found in the secondary zone may be attributed to the amount of available spawning habitat available near Ives and Pierce Islands. The overall increase in fall chinook salmon redds found during 2002 is consistent with the overall upriver fall chinook salmon run during 2002, which was significantly above the 10-year average (1993 to 2002) recorded at Bonneville Dam.

The maximum depth redds were detected during 2002 was $8.5 \mathrm{~m}$, which was the deepest redds have been detected since the surveys began in 1999. The majority of the redds were found in water depths $<5 \mathrm{~m}$. Substrate measurements made at the redd locations were predominately comprised of medium cobble ( 7.6 to $15.2 \mathrm{~cm}$ in diameter). River flows during both the November and December surveys were similar averaging near $125 \mathrm{kcfs}$. The stable flows during the spawning period probably contributed to the redds found spread throughout the primary search zone and extending down to the secondary zone.

The total area used by adult fall chinook salmon for spawning in 2002 was 9.31 ha, which is the largest area utilized during the last 4 years of surveys by PNNL (Table 4). This area dose not include surveys conducted by other agencies that documented fall chinook redds in shallow water nearer the islands. 
Table 4. Fall chinook redd counts and approximate spawning areas from 1999-2002 near Ives and Pierce Islands.

\begin{tabular}{|l|c|c||}
\hline Year & Redds (n =) & $\begin{array}{c}\text { Approximate Spawning } \\
\text { Area (ha) }\end{array}$ \\
\hline 1999 & 64 & 4.0 \\
\hline 2000 & 76 & 6.3 \\
\hline 2001 & 43 & 4.9 \\
\hline 2002 & 192 & 9.3 \\
\hline
\end{tabular}




\section{References}

Burner, C.J. 1951. Characteristics of spawning nests of Columbia River salmon. Fishery Bulletin 61, Volume 52. U.S. Fish and Wildlife Service. Washington, D.C.

Chapman, D.W., D.E. Weitkamp, T.L. Welsh, and T.H. Schaldt. 1983. Effects of minimum flow regimes on fall chinook salmon spawning at Vernita Bar 1978-1982. Don Chapman Consultants, McCall, Idaho, and Parametrix, Inc., Bellevue, Washington.

Dauble, D.D., R.P. Mueller, R.L. Johnson, W.V. Mavros, and C.S. Abernethy. 1999. Surveys of fall chinook salmon spawning downstream of Lower Snake River hydroelectric projects. Summary Report for 1993-1998. Prepared by Pacific Northwest Laboratory, Richland, Washington, for the U.S. Army Corps of Engineers, Walla Walla District, Walla Walla, Washington.

FPC. 2003. Fish Passage Center. http://www.fpc.org/Index.html. 2501 SW First Ave, Suite 230, Portland, Oregon.

Hymer, J. 1997. Results of studies on chinook spawning in the mainstem Columbia River below Bonneville Dam. Columbia River Progress Report 97-9. Washington Department of Fish and Wildlife, Battle Ground, Washington.

Mueller R.P. and D.D. Dauble 2000. Evidence of deepwater spawning of fall chinook salmon (Oncorhynchus tshawytscha) spawning near Ives and Pierce Islands of the Columbia River. Annual 1999, Report to Bonneville Power Administration, Contract No. 00000652-2, Project No. 1999-00304, 19 electronic pages (BPA report DOE/BP00000652-2)

Mueller R.P. 2001. Deepwater spawning of fall chinook salmon (Oncorhynchus tshawytscha) near Ives and Pierce Island of the Columbia River, Annual 2000, Report to Bonneville Power Administration, Contract No. 00000652, Project No. 1999-00304, 27 electronic pages, (BPA Report DOE/BP-00000652-6).

Mueller R.P. 2002. Deepwater spawning of fall chinook salmon (Oncorhynchus tshawytscha) near Ives and Pierce Island of the Columbia River. Project No. 199900304, 27 electronic pages, (BPA Report DOE/BP-00000652-10).

Platts, W.S., W.F. Megahan, and G.W. Minshall. 1983. Methods for evaluating stream, riparian, and biotic conditions. Technical Report INT-138, U.S. Forest Service, Washington D.C. 
Van der Naald, R. Clark, and B. Spellman 2000-2001. Evaluation of fall chinook and chum salmon spawning below Bonneville, The Dalles, John Day, and McNary Dams, prepared by Oregon Department of Fish and Wildlife for Bonneville Power Administration, Contract No. 1999-00301, Project No. 1999-00301, 33 electronic pages (BPA report DOE/BP-00004028-1).

Van der Naald, W., R. Clark, B. Spellman 2001-2002. Evaluation of fall chinook and chum salmon spawning below Bonneville, The Dalles, John Day and McNary Dams, prepared by Oregon Department of Fish and Wildlife for Bonneville Power Administration, Project No. 1999-00301, 33 electronic pages (BPA report DOE/BP00004028-2).

Visser, R.H. 2000. Utilizing remotely sensed imagery and GIS to monitor and research salmon spawning: A case study of the Hanford Reach fall chinook (Oncorhynchus tshawytscha). PNNL-13177, prepared by Pacific Northwest National Laboratory, Richland, Washington, for the U. S. Department of Energy. 
Appendix A 


\section{Appendix A}

PNNL Redd Coordinate Description

\begin{tabular}{|l|l|}
\hline \multicolumn{1}{|c|}{ Projection } & \multicolumn{1}{c|}{ Stateplane } \\
\hline \hline Zone & WA South 4602 \\
\hline Datum & NAD83 \\
\hline Units & Meters \\
\hline Vertical Datum & NGVD29 \\
\hline
\end{tabular}

\begin{tabular}{|c|c|c|c|c|}
\hline Number & Northing & Easting & $\begin{array}{c}\text { Depth } \\
(\mathrm{m})\end{array}$ & $\begin{array}{c}\text { Substrate Size } \\
(\mathrm{cm})\end{array}$ \\
\hline 1 & 32880.81 & 382916.05 & 0.91 & $\mathrm{n} / \mathrm{a}$ \\
\hline 2 & 32860.30 & 382868.43 & 0.91 & 13.07 \\
\hline 3 & 32871.84 & 382904.10 & 1.07 & 11.39 \\
\hline 4 & 32858.29 & 382873.43 & 1.22 & 8.61 \\
\hline 5 & 32814.79 & 382819.51 & 1.22 & 9.64 \\
\hline 6 & 32801.55 & 382779.80 & 1.22 & 6.47 \\
\hline 7 & 32783.11 & 382749.59 & 1.22 & 15.07 \\
\hline 8 & 32947.68 & 383034.78 & 1.22 & 9.21 \\
\hline 9 & 32888.57 & 382941.88 & 1.22 & 14.07 \\
\hline 10 & 32890.80 & 382932.72 & 1.22 & 11.02 \\
\hline 11 & 32831.04 & 382835.79 & 1.22 & 7.86 \\
\hline 12 & 32825.34 & 382815.94 & 1.22 & 10.38 \\
\hline 13 & 32970.22 & 383110.77 & 1.37 & 9.36 \\
\hline 14 & 32852.55 & 382881.25 & 1.37 & 12.68 \\
\hline 15 & 32781.81 & 382778.98 & 1.37 & 8.60 \\
\hline 16 & 32883.76 & 382925.56 & 1.37 & 8.37 \\
\hline 17 & 32809.13 & 382831.51 & 1.37 & 11.24 \\
\hline 18 & 32857.81 & 382914.46 & 1.46 & 11.06 \\
\hline 19 & 32985.65 & 383140.98 & 1.52 & 12.86 \\
\hline 20 & 32914.11 & 383038.16 & 1.52 & 12.62 \\
\hline 21 & 32902.67 & 383021.39 & 1.52 & 10.87 \\
\hline 22 & 32855.11 & 382935.35 & 1.52 & 11.83 \\
\hline 23 & 32848.72 & 382883.83 & 1.52 & 11.46 \\
\hline 24 & 32839.82 & 382894.64 & 1.52 & 11.00 \\
\hline 25 & 32763.18 & 382745.81 & 1.52 & 9.23 \\
\hline 26 & 32919.74 & 383016.43 & 1.52 & 10.37 \\
\hline 27 & 32840.17 & 382882.74 & 1.52 & 8.13 \\
\hline 28 & 32895.32 & 382985.34 & 1.55 & 8.21 \\
\hline 29 & 32776.25 & 382818.82 & 1.68 & 15.32 \\
\hline 30 & 32954.03 & 383191.22 & 1.68 & 13.55 \\
\hline 31 & 32918.78 & 383036.55 & 1.68 & 13.54 \\
\hline
\end{tabular}




\begin{tabular}{|c|c|c|c|c|}
\hline Number & Northing & Easting & $\begin{array}{c}\text { Depth } \\
(\mathrm{m})\end{array}$ & $\begin{array}{c}\text { Substrate Size } \\
\text { (cm) }\end{array}$ \\
\hline 32 & (32892.73 & 382990.03 & $\overline{c 1.68}$ & $\begin{array}{l}10.98 \\
\end{array}$ \\
\hline 33 & 32881.43 & 382950.12 & 1.68 & 14.66 \\
\hline 34 & 32875.98 & 382984.77 & 1.74 & 13.56 \\
\hline 35 & 32885.12 & 383027.75 & 1.77 & 12.92 \\
\hline 36 & 33005.14 & 383203.16 & 1.83 & 10.76 \\
\hline 37 & 32898.39 & 382994.34 & 1.83 & 9.81 \\
\hline 38 & 32891.10 & 382997.44 & 1.83 & 9.40 \\
\hline 39 & 32744.02 & 382739.75 & 1.83 & 9.25 \\
\hline 40 & 32921.14 & 383054.24 & 1.83 & 9.15 \\
\hline 41 & 32905.35 & 383027.85 & 1.83 & 11.42 \\
\hline 42 & 32810.57 & 382849.18 & 1.83 & 11.88 \\
\hline 43 & 32792.04 & 382837.52 & 1.83 & 11.57 \\
\hline 44 & 32746.60 & 382767.47 & 1.83 & 13.00 \\
\hline 45 & 32861.59 & 382957.59 & 1.92 & 13.28 \\
\hline 46 & 32799.30 & 382864.84 & 1.92 & 12.48 \\
\hline 47 & 32748.05 & 382761.79 & 1.92 & 9.79 \\
\hline 48 & 32834.28 & 382927.65 & 1.98 & 11.63 \\
\hline 49 & 32790.73 & 382848.52 & 1.98 & 8.63 \\
\hline 50 & 32818.47 & 382901.03 & 2.04 & 9.17 \\
\hline 51 & 32814.01 & 382892.82 & 2.04 & 9.73 \\
\hline 52 & 32859.90 & 382993.25 & 2.13 & 12.47 \\
\hline 53 & 32903.33 & 383045.79 & 2.13 & 10.66 \\
\hline 54 & 32892.67 & 383033.13 & 2.13 & 11.62 \\
\hline 55 & 32847.06 & 382946.06 & 2.13 & 10.46 \\
\hline 56 & 32802.99 & 382887.71 & 2.16 & 9.87 \\
\hline 57 & 32794.10 & 382877.36 & 2.16 & 9.91 \\
\hline 58 & 32898.20 & 383039.87 & 2.19 & 10.41 \\
\hline 59 & 32730.97 & 382765.26 & 2.19 & 10.92 \\
\hline 60 & 32753.36 & 382792.60 & 2.23 & 9.40 \\
\hline 61 & 32925.44 & 383041.93 & 2.26 & 8.38 \\
\hline 62 & 32747.67 & 382786.59 & 2.26 & 9.91 \\
\hline 63 & 32885.91 & 383010.09 & 2.26 & 11.43 \\
\hline 64 & 32875.59 & 383030.79 & 2.29 & 7.62 \\
\hline 65 & 32745.67 & 382791.78 & 2.29 & 8.38 \\
\hline 66 & 32808.67 & 382911.14 & 2.32 & 17.53 \\
\hline 67 & 32751.25 & 382816.12 & 2.35 & 9.14 \\
\hline 68 & 32843.75 & 382977.36 & 2.38 & 9.65 \\
\hline 69 & 32960.09 & 383138.74 & 2.44 & $n / a$ \\
\hline 70 & 32892.08 & 383043.57 & 2.44 & 9.65 \\
\hline 71 & 32854.84 & 382993.47 & 2.44 & 10.16 \\
\hline 72 & 32771.40 & 382865.64 & 2.44 & 11.18 \\
\hline 73 & 32656.94 & 381799.99 & 2.44 & 15.49 \\
\hline 74 & 32886.58 & 383035.58 & 2.44 & $n / a$ \\
\hline 75 & 32764.60 & 382845.07 & 2.56 & 11.94 \\
\hline 76 & 32821.51 & 382936.68 & 2.56 & 9.91 \\
\hline 77 & 32969.53 & 383174.79 & 2.59 & 8.89 \\
\hline 78 & 32844.05 & 383000.47 & 2.59 & 9.65 \\
\hline 79 & 32830.63 & 382970.16 & 2.59 & 12.70 \\
\hline 80 & 32720.37 & 382752.93 & 2.68 & 11.68 \\
\hline
\end{tabular}




\begin{tabular}{|c|c|c|c|c|}
\hline Number & Northing & Easting & $\begin{array}{c}\text { Depth } \\
(\mathrm{m})\end{array}$ & $\begin{array}{c}\text { Substrate Size } \\
(\mathrm{cm})\end{array}$ \\
\hline 81 & 1032843.85 & 382986.49 & 2.74 & 10 \\
\hline 82 & 32763.01 & 382878.39 & 2.74 & 12.19 \\
\hline 83 & 32633.82 & 382093.91 & 2.74 & 16.76 \\
\hline 84 & 32989.36 & 383200.99 & 2.80 & 11.43 \\
\hline 85 & 32865.46 & 383035.77 & 2.83 & 5.84 \\
\hline 86 & 32831.87 & 382988.82 & 2.83 & 8.38 \\
\hline 87 & 32899.76 & 383057.25 & 2.93 & 9.65 \\
\hline 88 & 32655.04 & 381760.33 & 2.99 & 8.89 \\
\hline 89 & 32944.43 & 383146.36 & 3.05 & 7.11 \\
\hline 90 & 32916.45 & 383098.59 & 3.05 & 8.89 \\
\hline 91 & 32914.09 & 383078.01 & 3.05 & 9.14 \\
\hline 92 & 32890.39 & 383078.42 & 3.05 & 9.91 \\
\hline 93 & 32890.38 & 383067.49 & 3.05 & 10.67 \\
\hline 94 & 32793.09 & 382939.73 & 3.05 & 10.92 \\
\hline 95 & 32769.66 & 382902.58 & 3.05 & 9.65 \\
\hline 96 & 32624.35 & 382097.86 & 3.11 & 15.24 \\
\hline 97 & 32876.91 & 383043.01 & 3.11 & 9.40 \\
\hline 98 & 32710.18 & 382756.62 & 3.11 & 10.41 \\
\hline 99 & 32945.22 & 383129.69 & 3.17 & 7.87 \\
\hline 100 & 32927.87 & 383132.50 & 3.20 & 8.13 \\
\hline 101 & 32874.52 & 383052.52 & 3.26 & 9.14 \\
\hline 102 & 32926.23 & 383101.61 & 3.29 & $n / a$ \\
\hline 103 & 32845.95 & 383046.78 & 3.32 & 7.87 \\
\hline 104 & 32966.26 & 383246.74 & 3.35 & 5.84 \\
\hline 105 & 32914.03 & 383111.42 & 3.35 & 8.13 \\
\hline 106 & 32615.97 & 382197.37 & 3.35 & 6.35 \\
\hline 107 & 32615.35 & 382185.31 & 3.35 & 9.14 \\
\hline 108 & 32638.50 & 381726.54 & 3.35 & 9.14 \\
\hline 109 & 32895.59 & 383070.06 & 3.41 & 7.87 \\
\hline 110 & 32853.09 & 383060.02 & 3.47 & 7.37 \\
\hline 111 & 32861.60 & 383077.81 & 3.51 & 8.13 \\
\hline 112 & 32967.17 & 383214.15 & 3.51 & 10.41 \\
\hline 113 & 32951.81 & 383173.36 & 3.51 & 4.83 \\
\hline 114 & 32928.27 & 383121.71 & 3.51 & 9.14 \\
\hline 115 & 32905.56 & 383111.52 & 3.54 & 5.33 \\
\hline 116 & 32902.92 & 383106.58 & 3.60 & 7.62 \\
\hline 117 & 32618.11 & 381737.31 & 3.60 & 6.35 \\
\hline 118 & 32916.07 & 383140.26 & 3.66 & 6.35 \\
\hline 119 & 32875.15 & 383091.53 & 3.66 & 10.16 \\
\hline 120 & 32839.28 & 383049.92 & 3.66 & 6.35 \\
\hline 121 & 32612.56 & 382161.80 & 3.66 & 6.60 \\
\hline 122 & 32615.43 & 382085.14 & 3.66 & 10.41 \\
\hline 123 & 32944.70 & 383179.16 & 3.72 & 10.16 \\
\hline 124 & 32619.09 & 382061.87 & 3.72 & 8.89 \\
\hline 125 & 32940.41 & 383175.85 & 3.81 & 9.40 \\
\hline 126 & 32855.81 & 383078.74 & 3.81 & 8.89 \\
\hline 127 & 32628.06 & 381699.45 & 3.84 & 10.67 \\
\hline 128 & 32605.33 & 382213.55 & 3.87 & 9.14 \\
\hline 129 & 32868.81 & 383099.56 & 3.90 & 16.51 \\
\hline
\end{tabular}




\begin{tabular}{|c|c|c|c|c|}
\hline Number & Northing & Easting & $\begin{array}{c}\text { Depth } \\
(\mathrm{m})\end{array}$ & $\begin{array}{c}\text { Substrate Size } \\
(\mathrm{cm})\end{array}$ \\
\hline 130 & 3032951.49 & 383233.95 & 3.96 & 8.38 \\
\hline 131 & 32944.19 & 383223.05 & 3.96 & 8.64 \\
\hline 132 & 32924.85 & 383185.56 & 3.96 & 9.65 \\
\hline 133 & 32617.19 & 381751.33 & 3.96 & 10.16 \\
\hline 134 & 32895.77 & 383114.25 & 3.96 & 9.40 \\
\hline 135 & 32609.19 & 3817713.74 & 3.96 & 8.64 \\
\hline 136 & 32972.75 & 383272.79 & 4.05 & 13.46 \\
\hline 137 & 32612.51 & 382047.00 & 4.08 & 11.18 \\
\hline 138 & 32913.63 & 383186.59 & 4.11 & 10.16 \\
\hline 139 & 32919.59 & 383154.51 & 4.11 & 9.91 \\
\hline 140 & 32933.41 & 383187.91 & 4.11 & 9.65 \\
\hline 141 & 32601.59 & 382200.83 & 4.11 & 7.87 \\
\hline 142 & 32902.06 & 383132.90 & 4.15 & 10.41 \\
\hline 143 & 32624.84 & 381869.29 & 4.21 & 14.73 \\
\hline 144 & 32931.72 & 383208.82 & 4.21 & 11.68 \\
\hline 145 & 32927.45 & 383226.97 & 4.27 & 8.13 \\
\hline 146 & 32902.25 & 383167.07 & 4.27 & $\mathrm{n} / \mathrm{a}$ \\
\hline 147 & 32893.06 & 383167.90 & 4.27 & 6.60 \\
\hline 148 & 32894.35 & 383153.51 & 4.27 & 5.84 \\
\hline 149 & 32945.50 & 383247.36 & 4.27 & 7.62 \\
\hline 150 & 32914.98 & 383152.78 & 4.27 & 7.62 \\
\hline 151 & 32619.65 & 381944.45 & 4.39 & 13.21 \\
\hline 152 & 32945.28 & 383258.92 & 4.42 & 8.13 \\
\hline 153 & 32620.13 & 381827.95 & 4.42 & 8.13 \\
\hline 154 & 32897.42 & 383169.45 & 4.42 & 9.14 \\
\hline 155 & 32598.30 & 382172.91 & 4.42 & 9.40 \\
\hline 156 & 32860.68 & 383137.24 & 4.51 & 9.14 \\
\hline 157 & 32944.12 & 383283.14 & 4.57 & $\mathrm{n} / \mathrm{a}$ \\
\hline 158 & 32609.04 & 381981.29 & 4.57 & 10.16 \\
\hline 159 & 32609.50 & 381783.97 & 4.57 & 9.14 \\
\hline 160 & 32932.59 & 383238.12 & 4.57 & 9.65 \\
\hline 161 & 32913.48 & 383199.25 & 4.57 & 7.11 \\
\hline 162 & 32599.28 & 381747.32 & 4.66 & 11.18 \\
\hline 163 & 32599.53 & 382055.33 & 4.82 & 8.89 \\
\hline 164 & 32596.19 & 381677.49 & 4.85 & 11.43 \\
\hline 165 & 32599.97 & 382012.82 & 4.88 & 9.40 \\
\hline 166 & 32591.10 & 382097.82 & 4.88 & 8.89 \\
\hline 167 & 32611.39 & 381926.80 & 4.88 & 13.46 \\
\hline 168 & 32950.42 & 383294.39 & 4.97 & 10.67 \\
\hline 169 & 32926.69 & 383256.99 & 5.00 & 9.91 \\
\hline 170 & 32601.90 & 381859.77 & 5.12 & 7.87 \\
\hline 171 & 32595.70 & 382070.99 & 5.18 & 9.91 \\
\hline 172 & 32918.87 & 383278.06 & 5.33 & 19.30 \\
\hline 173 & 32899.55 & 383239.22 & 5.33 & 14.48 \\
\hline 174 & 32591.32 & 38181.92 & 5.64 & 17.02 \\
\hline 175 & 32924.72 & 383291.91 & 5.79 & 11.94 \\
\hline 176 & 32587.22 & 381946.27 & 5.79 & 11.18 \\
\hline 177 & 32586.60 & 381765.30 & 5.79 & 11.18 \\
\hline 178 & 32584.01 & 381836.31 & 5.94 & 9.65 \\
\hline
\end{tabular}




\begin{tabular}{||c|c|c|c|c||}
\hline \hline Number & Northing & Easting & $\begin{array}{c}\text { Depth } \\
(\mathrm{m})\end{array}$ & $\begin{array}{c}\text { Substrate Size } \\
(\mathrm{cm})\end{array}$ \\
\hline \hline 179 & 32707.23 & 382816.70 & 6.10 & 10.92 \\
\hline 180 & 32582.38 & 381989.65 & 6.16 & 18.29 \\
\hline 181 & 32586.02 & 381783.20 & 6.19 & 8.64 \\
\hline 182 & 32580.38 & 382148.00 & 6.34 & 9.91 \\
\hline 183 & 32859.16 & 383189.45 & 6.40 & 12.19 \\
\hline 184 & 32581.67 & 381897.08 & 6.46 & 8.64 \\
\hline 185 & 32582.07 & 382910.41 & 6.71 & $\mathrm{n} / \mathrm{a}$ \\
\hline 186 & 32571.20 & 381817.67 & 7.01 & 6.60 \\
\hline 187 & 32577.27 & 381787.47 & 7.01 & $\mathrm{n} / \mathrm{a}$ \\
\hline 188 & 32569.61 & 381877.03 & 7.07 & 9.65 \\
\hline 189 & 32562.85 & 381893.47 & 7.16 & 12.19 \\
\hline 190 & 32563.86 & 381838.05 & 7.32 & 8.64 \\
\hline 191 & 32583.00 & 382181.17 & 7.92 & 6.86 \\
\hline 192 & 32560.24 & 381728.88 & 7.92 & 7.37 \\
\hline 193 & 32568.50 & 382118.99 & 8.53 & 10.92 \\
\hline
\end{tabular}

